\title{
EFFECT OF TRANSFORMATIONAL LEADERSHIP \\ ON ORGANIZATIONAL COMMITMENT THROUGH \\ THE INTERACTION OF PSYCHOLOGICAL EMPOWERMENT
}

\author{
Thaneswary Raveendran \\ Department of Human Resource Management, \\ University of Jaffna, Sri Lanka \\ Email: rthanes@univ.jfn.ac.lk
}

\begin{abstract}
The present study was aimed at examining the association between transformational leadership and organizational commitment, and the mediating role of psychological empowerment in the association between them. Eventhough there are plenty of empirical studies on the association between leadership styles and organizational commitment in various contexts, there is inadequate evidence in the Sri Lankan context. Considering the gap in the current literature, the study was conducted on the Development Officers working in the public sector organizations in the Jaffna region. For this purpose a sample of 235 Development Officers attached to the District Secretariat and Divisional Secretariats was selected based on random sampling method. The transformational leadership was measured using MLQ- Form 5x (Bass \& Avolio, 2000), organizational commitment was measured using OCQ (Meyer \& Allen, 1997) and empowerment was measured using Empowerment Scale (Spreitzer, 1995). Exploratory factor analysis and Confirmatory factor analysis were performed to validate the data and then the constructs were integrated in the structural equation model to find the relationships among the variables. The results revealed that the direct effect of transformational leadership on organizational commitment is not significant $(b=.011, p>.05)$. The effect of transformational leadership on psychological empowerment is significant $(\mathrm{B}=.621, \mathrm{p}=.001)$. The results confirm that psychological empowerment doesn't act as a mediator in the effect of transformational leadership on organizational
\end{abstract}


commitment (direct effect and indirect effect are not significant). As the present study concludes transformational leadership is not effective in promoting commitment of Development Officers working at District and Divisional Secretariats, future research should cover other public sector and private sector organizations. As the operative level employees' perception of their superiors' (first line leaders) leadership style was studied, future studies need to focus on the middle and top level leaders' leadership styles and the resultant outcomes.

Keywords: Development Officers; Organizational commitment; Psychological empowerment; Transformational leadership

\section{Introduction}

Leadership research is vital on the grounds that it leads towards identifying new, more developed and successful approaches and assessment of the current leadership approaches (Barbuto, 2005). Also, leadership research gives direction regarding the qualities and behaviors of leaders that lead to positive results to organizations as well as employees. In addition, each and every organization is unique to some degree in relation to another and has distinctive culture, practices and systems. Therefore, it becomes necessary to conduct specific leadership research to determine the best leadership style or styles for a particular organization or context (Avolio et al., 2009). According to Northouse (2007), leadership is a process whereby an individual influences a group of people to attain a common goal. Jong and Hartog (2007) have mentioned that leadership is a process of influencing others to get desired results. In other words, leadership is the process whereby a person influences others to willingly exert efforts and use the abilities towards accomplishing goals of the group and organization (Nel et al., 2004).

Despite plenty of studies has been conducted on leadership all over the world, there are very few studies available in the literature to understand the association between leaders' leadership styles and employees' organizational commitment and the mediation effect of psychological empowerment in the relationship between transformational leadership style and organizational commitment in the Sri Lankan context. Review of existing literature revealed that only a few studies conducted in the subject of leadership in Sri Lanka. For example, Dhammika, 
Ahmad and Sam (2013) examined effects of leadership styles on union and organizational commitment in public sector organizations in Sri Lanka; Raveendran \& Gamage (2019) studied the mediating effect of organizational commitment in the effect of transformational leadership on employee performance in the Divisional Secretariats in the Jaffna District. Likewise few other researches have been reported (Jayakody, 2008; KasturiArachchi, 2011; Athukorala, Perera \& Meedeniya, 2016; Fernando, 2018). However, it is very rare to come across the studies on this phenomenon in the Sri Lankan public sector.

In the current study, the researcher identified an apparent knowledge gap in the prior research concerning the influence of leadership styles on employee performance as there are conflicting findings in the literature. There is no clear evidence about which leadership style is effective in enhancing employee performance in the public sector in Sri Lanka. Furthermore previous research has separately applied different types of leadership theories such as autocratic, democratic and laissez faire leadership, servant leadership, authentic leadership and, people oriented and task oriented leadership to examine the variables of interest. For example, Hemakumara (2011) examined the connection between the directive and supportive leadership styles and team cohesiveness in the public sector in Sri Lanka. However, there is gap in the current research literature examining the influence of transformational leadership style on employee outcomes in the Sri Lankan context. In addition, the prior research did not address the interaction effect of empowerment in the influence of transformational leadership style on employees' organizational commitment. The association between the variables should be explored further to provide a clear understanding in the field. Therefore, research in this phenomenon is necessary to add body of knowledge in the field of leadership and to improve public service.

\subsection{Objective of the Study}

Even though there is plenty of research on leadership on various employee outcomes, there is little evidence on the influence of transformational leadership on employees' organizational commitment in the Sri Lankan context. The main objective of the present study was to examine the association between 
transformational leadership and organizational commitment, and the mediating role of psychological empowerment in the association between them.

\subsection{Research Questions}

The study attempts to find the answer for the following research questions.

- To what extent transformational leadership influences organizational commitment of Development Officers in the public sector?

- Does psychological empowerment mediate the influence of transformational leadership on organizational commitment of Development Officers in the public sector?

\section{Review of Literature}

\subsection{Transformational leadership}

Transformational leadership is concerned with how a leader inspires and influences the followers to make them behave in a desired way. The theory of transformational leadership was first introduced by a leadership expert, James McGregor Burns. Burns (1978) pointed out that transformational leadership style can be seen when leaders and followers make each other to move on to high level of moral and increased motivation. These types of leaders modify the beliefs and attitudes of the employees by inspiring them. They create a vision and articulate it to the followers and motivate them to achieve particular goals. Transformational leaders have the ability to inspire followers to make changes in their perceptions and expectations, and motivate them to reach the goals set for them. Later, Bernard M. Bass expanded upon Burns' idea to develop what is now referred to as Bass' (1985) Transformational Leadership Theory. Walumbwa, Avolio and Zhu (2008) reported that transformational leaders enhance perceptions of self-efficacy of followers by communicating high expectations, and encouraging them to accomplish the mission of the organization.

Transformational leadership integrates the basics of empathy, sensitivity, compassion, innovation and improved relationship (Jin, 2010). It promotes a climate 
of trust, raises employees' confidence, and persuades their individual development. Bass (1985), Hater and Bass (1988), and Bass and Avolio (1990) have proposed five subscales or dimensions of transformational leadership: inspirational motivation, idealized influence (attributes), idealized influence (behaviour), individualized consideration and intellectual stimulation.

Inspirational motivation of transformational leadership refers to the articulation and representation of a vision by the leader. According to Sarros and Santora (2001), most transformational leaders had the ability to provide inspirational motivation to their followers. Intellectual stimulation includes challenging the assumptions of followers' beliefs, the analysis of problems they face and the solutions they generate (Rowold, 2005). Transformational leaders stimulate change and instill creativity and thus followers are encouraged to approach problems in new ways. Individualized consideration means considering individual needs of followers and developing their strengths. Key indicators of individualized consideration include encouragement, care for workers, coaching them, consulting them and adopting an open approach (Sarros \& Santora, 2001). Idealized influence involves the ability of building confidence in the leader. Without such confidence in the leader's motives and aims, any attempt to direct the organization may cause great resistance. The major indicators of idealized influence consists of role modeling, values creation and articulation, sense of purpose, confidence in followers, self-esteem, self-determination, self-confidence, emotional control, etc (Sarros \& Santora, 2001). Idealized influence is divided into two types namely attributes (traits assigned to a leader) and behaviour (what one does). Idealized influence (attributes) refers to the attribution of charisma to the leader whereas idealized influence (behaviour) emphasizes a collective sense of mission and values and acing upon these values (Rowold, 2005).

\subsection{Organizational commitment}

The success and performance of organizations partially depend on the commitment of employees toward the organization. It encompasses the readiness to perform the tasks for the sake of the department or organization. The organization's success depends on how it employs the most talented and competent people how 
it promotes organizational commitment among the employees (Baken, Büyükbee \& Erahan, 2011). Commitment to organization is concerned with the situation where an employee is in line with specific organizational goals and maintains membership in the organization (Robbins \& Judge, 2007). Organizational commitment is defined as a psychological state that characterizes the employee's relationship with the organization, and has implications for the decision to continue membership in the organization (Meyer \& Allen, 1991).

There are three components of commitment: affective, continuance and normative commitment (Meyer \& Allen, 1991). Affective commitment is the desire to continue to work in the organization and identify with the organization. Meyer and Allen (1997) define affective commitment as the employee's emotional attachment to, identification with, and involvement in the organization. They define continuance component as commitment that is based on the costs that the employee associates with leaving the organization. Normative commitment is a feeling of obligation to continue employment (Meyer \& Allen, 1997).

\subsection{Psychological empowerment}

Conger and Kanungo (1988) defined empowerment as the motivational concept of self efficacy. According to Thomas and Velthouse (1990), empowerment is a broad term and it cannot be captured by a single concept. They defined empowerment as intrinsic task motivation manifested in a set of four cognitions reflecting an individual's view about his or her work role: meaning, competence, self determination, and impact. Meaning refers to the value of a work goal, judged in relation to an individual's own ideals and standards (Thomas \& Velthouse, 1990). Competence is an individual's belief in his or her capability to do the activities with skills (Gist, 1987). Self determination is an individual's sense of having choice in initiating actions and regulating them (Deci, Connel \& Ryan, 1989). Impact refers to the extent to which an individual can influence the strategic and operating outcomes in job (Ashforth, 1989). 


\subsection{Relationship between Transformational leadership and organizational}

commitment

Transformational leaders encourage followers to find new ways to solve problems and to tackle with the challenges and, as a result, high level of commitment among the followers is possible. Transformational leadership behaviour acts as an antecedent of many workplace behaviours of employees as well as organizational performance and there are some mediating factors in the effect of transformational style on employee outcomes such as engagement, empowerment, trust on leader and so on. For example, McCann, Langford and Rawlings (2006) surveyed 182 followers working under 29 leaders in 17 organizations and found that charismatic transformational leadership behaviours of leaders strongly related to followers' belief and organizational commitment. A survey of 323 front line workers from a hotel found that engagement partially mediates the relationship between transformational leadership and employee performance (Buil, Martínez \& Matute, 2019). Mohamad, Aziz, Sadq and Othman (2020) examined the effect of the five components of transformational leadership on employee effectiveness by surveying a sample of 76 employees working at the Ministry of Higher Education and Scientific Research in the Kurdistan Regional Government. The results revealed that inspirational motivation impacts employee effectiveness. Many researchers (e.g. Anwar \& Ahmad, 2012; Bass \& Avolio, 1994; Lo, Ramayah \& Min, 2009; Marmaya, Hitam, Torsiman \& Balakrishnan, 2011) agreed that transformational style is directly related with organizational commitment. Transformational leaders work with followers to identify the necessary changes and create a vision. Their role is to guide and motivate them and execute the changes with the committed members of the different groups.

However, there are some conflicting findings in this connection. For example, Abasilim et al. (2016) examined the effects of transformational leadership on organizational commitment among academic staff in a Nigerian private university and found that transformational leadership has no significant effects on organizational commitment. They also found that the participants who rated themselves as having average commitment also rated their leaders as having high transformational leadership style. Hence, they recommended that, as the finding 
is antithetical to the literature, there is a need for further enquiry. Considering the literature, the hypothesis 1 has been formulated as follows.

H1: Transformational leadership positively influences organizational commitment

\subsection{Relationship between transformational leadership and psychological empowerment}

An outcome of transformational leadership is the empowerment of followers and, (Burns, 1978). through empowerment, the followers are transformed into effective leaders. Transformational leaders can also empower followers by providing both positive emotional support and opportunities to experience task mastery. Moreover, followers can be empowered by encouragement and positive persuasion from the transformational leader (Bass, 1985; Boamah, Laschinger, Wong \& Clarke, 2018). In the study of school teachers, Allameh, Heydari, and Davoodi (2012) found that the dimensions of transformational leadership had a significant relationship with psychological empowerment.

Spreitzer (2008) pointed out that the psychological empowerment theory proposes that transformational leaders promote employee empowerment. Such leaders contribute for the success of the companies and motivate employees to perform extremely well towards the organizational and individual goals (Spreitzer, 2008). In addition, they promote psychological empowerment by providing them with autonomy, building their confidence, enhancing their abilities to capitalize on opportunities and promoting their performance (Conger \& Kanungo, 1988). Few studies (Boonyarit, Chomphupart, \& Arin, 2010; Allameh, Heydari \& Davoodi, 2012; Sagnak, Kuruoz, Polat \& Soylu, 2015) have reported that transformational leadership influences psychological empowerment among teachers. Krishnan (2012) reported that transformational leadership predicts psychological empowerment among managers in a large manufacturing organization in India. Fang-guo (2013) examined the association between the variables surveying managers and employees in 144 restaurants in China and found that transformational leadership is correlated with empowerment. By surveying 310 managers in three private information technology organizations in India, Jha (2013) reported that there is significant positive relationship between transformational leadership 
and psychological empowerment. Likewise, several studies (Pradhan, Panda, \& Jena, 2017; Suer, 2017; Avolio et al., 2004; Martin \& Bush, 2006; Lan \& Chong, 2015; Han, Seo, Yoon, \& Yoon, 2016; Balaji \& Krishnan, 2014) confirmed that transformational leadership and psychological empowerment are significantly correlated.

Allameh, Heydari \& Davoodi (2012) reported that transformational leadership and psychological empowerment are significantly associated and the dimensions idealized influence, individualized consideration and inspirational motivation are the important determinants of psychological empowerment. However, Lan and Chong (2015) found that, even though transformational leadership and psychological empowerment are positively correlated, not all dimensions of transformational leadership are correlated to psychological empowerment. Based on the empirical evidences, the hypothesis 2 has been established.

H2: Transformational leadership positively influences psychological empowerment.

2.6 Mediating effect of psychological empowerment in the relationship between transformational leadership and organizational commitment

Many researchers have examined the indirect effect of transformational leadership on organizational commitment through psychological empowerment (e.g. Kark, Shamir \& Chen, 2003; Boonyarit, Chomphupart \& Arin, 2010; Ismail, Mohamed, Sulaiman, Mohamad \& Yusuf, 2011). Ismail et al (2011) surveyed 118 employees in a US firm operating in Malaysia and found that psychological empowerment mediates the influence of transformational leadership on organizational commitment. Likewise, Avolio, et al. (2004) surveyed 520 staff nurses of a public hospital in Singapore and reported that psychological empowerment mediates the relationship between transformational leadership and organizational commitment. Ahmadi (2014) and Shah et al (2001) also have reported the same finding.

Abdulrab, Zmrah, Almaamari and Al-Tahitah (2017) reported that leadership styles of Malaysian public universities should focus on promoting psychological empowerment of academic staff so as to encourage positive behaviours which, in turn, lead to performance and effectiveness of the universities. In the study 
of school teachers, Allameh, Heydari and Davoodi (2012) reported that the components of transformational leadership had a significant relationship with psychologicalempowerment. However, few transformationalleadershipdimensions are not significantly associated with psychological empowerment. For example, Ibrahim, Ismail, Mohamed, Salim, and Yusuf (2015) surveyed employees in a foreign manufacturing company operating in Free Trade Zone, Malaysia and have reported that idealized influence does not significantly influence psychological empowerment, but intellectual stimulation and individualized consideration are significantly associated with psychological empowerment. According to Attari (2013), transformational leadership has a strong effect on psychological empowerment and its dimensions namely, meaning, competence, self determination and impact. Based on the literature, the hypothesis 3 was established as follows.

H3: Psychological empowerment mediates the influence of transformational leadership on organizational commitment.

\section{Methodology}

\section{Operationalization}

The concepts and variables taken for the study were operationalized as shown in Table 1.

\section{Table 1: Operationalization}

\begin{tabular}{|l|l|l|}
\hline Concept & Dimensions & Measure/Instrument \\
\hline \multirow{4}{*}{$\begin{array}{l}\text { Transformational } \\
\text { Leadership }\end{array}$} & $\begin{array}{l}\text { Idealized influence (attributes } \\
\text { and behaviour) }\end{array}$ & $\begin{array}{l}\text { Multifactor Leadership } \\
\text { Questionnaire (MLQ) } \\
\text { Form 5X - Rater form } \\
\text { - Intellectual stimulation } \\
\text { Individualized consideration }\end{array}$ \\
& & \\
& Bass and Avolio (2000) \\
\hline
\end{tabular}




\begin{tabular}{|l|l|l|}
\hline $\begin{array}{l}\text { Organizational } \\
\text { commitment }\end{array}$ & $\begin{array}{l}\text { Affective commitment } \\
\text { C Continuance commitment }\end{array}$ & $\begin{array}{l}\text { Organizational } \\
\text { Commitment Questionnaire } \\
\text { developed by Meyer and } \\
\text { Allen (1997) }\end{array}$ \\
\hline Psychological & $\begin{array}{l}\text { Meaning } \\
\text { Empowerment }\end{array}$ & $\begin{array}{l}\text { Empowerment scales of } \\
\text { Spreitzer (199) }\end{array}$ \\
& - Self-determination & \\
\hline
\end{tabular}

The employees working in the Divisional Secretariats and District Secretariat of Jaffna District were considered for the study. The target population was the Development Officers working in the said organizations and the samples were selected randomly. A sample of 235 Development officers participated in the study. Out of the 235 participants, 23\% were from District Secretariat and the remaining $77 \%$ were from the Divisional Secretariats in Jaffna District. The study is explanatory in nature and cross sectional survey method was employed.

A pilot study was conducted with 32 employees selected based on convenience sampling to ensure the reliability of the instruments and, based on the feedback of respondents, the items were rephrased or modified to avoid ambiguity and confusion.

\section{Analysis}

The study involves Exploratory Factor Analysis (EFA) to confirm the factor structure and Confirmatory Factor Analysis (CFA) to confirm validity and reliability of the constructs. Structural Equation Modeling (SEM) was performed to test the hypotheses of the current study. Initially, the scale reliability was examined using Cronbach's alpha of each subscale before performing factor analysis. The alpha values reported in Table 2 show that the alpha of most of the subscales is above the minimum requirement of 0.7 (Nunnally, 1978). However, a coefficient between 0.6 and 0.7 is deemed to be acceptable if the Cronbach's alpha of other constructs are high (Hair, Black, Babin \& Anderson, 2014; Malhotra \& Peterson, 2006). Thus, in the current study, the data are reliable and appropriate for the factor analysis. 


\begin{tabular}{lll} 
& items & Alpha \\
\hline Transformational leadership & & \\
Intellectual stimulation & 4 & 0.678 \\
Inspirational motivation & 4 & 0.658 \\
Individual consideration & 4 & 0.727 \\
Idealized influence (attributes) & 4 & 0.601 \\
Idealized influence (behavior) & 4 & 0.800 \\
Organizational commitment & & \\
Affective commitment & 6 & 0.721 \\
Continuance commitment & 6 & 0.882 \\
Normative commitment & 6 & 0.730 \\
Psychological empowerment & & \\
Meaning & 3 & 0.807 \\
Competence & 3 & 0.777 \\
Self-determination & 3 & 0.680 \\
Impact & 3 & 0.638 \\
\hline
\end{tabular}

Source: Survey data

In the sample, $72 \%$ are females and $28 \%$ are males. In case of marital status, the $69 \%$ are married and the remaining are unmarried. $48 \%$ of the sample falls in the age group $26-35$ years, $31 \%$ falls in the age group 36-45 years and very less percentage falls in the age group below 25 years $(12 \%)$ as well as above 46 years $(9 \%)$. Majority of the sample $(52 \%)$ has below 5 years experience whereas very less percentage of samples (5\%) falls in the experience of above 20 years.

In the current study, even though established instruments were used to collect the data, Exploratory Factor Analysis (EFA) was performed to confirm the factor structure of the particular instruments. Through EFA, the factors of transformational leadership, organizational commitment and psychological empowerment were extracted and a few items with low factor loading were removed. Principal Component Analysis method was used for extraction of factors and Promax Rotation method was used. 
Table 3: EFA for Transformational Leadership

\begin{tabular}{|c|c|c|c|c|c|}
\hline \multicolumn{6}{|c|}{ Pattern Matrix ${ }^{\mathbf{a}}$} \\
\hline & \multicolumn{5}{|c|}{ Component } \\
\hline & 1 & 2 & 3 & 4 & 5 \\
\hline ID_IN_A2 & & .829 & & & \\
\hline ID_IN_A3 & & .597 & & & \\
\hline ID_IN_A4 & & .856 & & & \\
\hline ID_IN_B1 & & & & .810 & \\
\hline ID_IN_B2 & & & & .535 & \\
\hline ID_IN_B4 & & & & .901 & \\
\hline IN_CN1 & .780 & & & & \\
\hline IN_CN2 & .418 & & & & \\
\hline IN_CN3 & .495 & & & & \\
\hline IN_CN4 & .825 & & & & \\
\hline IN_MO1 & & & & & .817 \\
\hline IN_MO2 & & & & & .800 \\
\hline IN_ST1 & & & .876 & & \\
\hline IN_ST2 & & & .740 & & \\
\hline IN_ST3 & & & .638 & & \\
\hline \multicolumn{6}{|c|}{ Total variance explained $-64.8 \%$} \\
\hline \multicolumn{6}{|c|}{ Determinant -0.004} \\
\hline \multicolumn{6}{|c|}{$\mathrm{KMO}-0.808$} \\
\hline
\end{tabular}

Note: ID_IN_A- Idealized Influence-Attributes; ID_IN_B: Idealized Influence-Behaviour;

IN_CN: Individualized Consideration; IN_MO: Inspirational Motivation; IN_ST: Intellectual Stimulation

Source: Survey Data

The Table 3 shows the factor structure of transformational leadership constructs. Few items of the construct with low factor loading were removed from the data set and a clear pattern matrix was obtained. The total variance explained by the subscales of transformational leadership is $64.8 \%$ and it is above the recommended limit of $60 \%$ (Hair, Black, Babin, Anderson, \& Tatham, 2006).

The Determinant of the R-matrix which tests for multicollinearity is 0.004 and it is greater than the cut-off value of 0.00001 (Sreejesh et al., 2014) for the 
transformational leadership sub-constructs. In addition, the value of Determinant is neither exact 0 nor exact 1 and thus it can be concluded that the correlation matrix obtained in EFA is neither an identity matrix nor a singular matrix (Sreejesh et al., 2014). This value also confirms the assumption that there are adequate interrelationships among the study items and none of the correlation coefficients are particularly large. Therefore, multicollinearity is not a problem for these data and thus there is no need to consider eliminating any item at this stage. As can be seen in the Table 3, the KMO value that verifies the sampling adequacy is 0.808 and the value is 'meritorious' according to Kaiser and Rice (1974). As the value is well above the acceptable limit of 0.5 (Kaiser \& Rice, 1974), the sample is sufficient for performing factor analysis and the factor analysis would yield reliable factors (Hutcheson \& Sofroniou, 1999).

Table 4: EFA for Organizational Commitment

\begin{tabular}{|l|c|c|c|}
\hline \multicolumn{4}{|c|}{ Pattern Matrix $^{\mathbf{a}}$} \\
\hline & 1 & 2 & 3 \\
\hline & .717 & & \\
\hline AF_CO1 & .831 & & \\
\hline AF_CO2 & .872 & & \\
\hline AF_CO3 & .861 & & \\
\hline AF_CO4 & .829 & & \\
\hline AF_CO5 & .839 & & .685 \\
\hline AF_CO6 & & & .412 \\
\hline CN_CO1 & & & .689 \\
\hline CN_CO2 & & & .565 \\
\hline CN_CO3 & & & .747 \\
\hline CN_CO4 & & .746 & \\
\hline CN_CO5 & & .769 & \\
\hline CN_CO6 & & .821 & \\
\hline NO_CO1 & & .810 & \\
\hline NO_CO2 & & & \\
\hline NO_CO3 & & & \\
\hline NO_CO4 & & & \\
\hline NO_CO5 & & & \\
\hline
\end{tabular}




\begin{tabular}{|l|r|l|}
\hline NO_CO6 & .802 & \\
\hline Total variance explained $-59.1 \%$ & & \\
Determinant -0.001 & \\
KMO -0.827 & \\
\hline
\end{tabular}

Note: AF_CO: Affective Commitment; CN_CO: Continuous Commitment; NO_CO: Normative Commitment

\section{Source: Survey data}

The Table 4 shows the factor structure of organizational commitment constructs. The total variance explained by the subscales of organizational commitment is $59.1 \%$ and it is very closer to the minimum requirement suggested by Hair et al (2006). The Determinant of the R-matrix which tests for multicollinearity is 0.001 and it is greater than the cut-off value of 0.00001 (Sreejesh et al., 2014) for the sub-constructs of organizational commitment. In addition, the value of Determinant confirms the assumption that there are adequate interrelationships among the study items and none of the correlation coefficients are particularly large. Therefore, multicollinearity is not a problem for these data. The KMO value that verifies the sampling adequacy is 0.827 is well above the acceptable limit of 0.5 (Kaiser \& Rice, 1974) and thus the sample is sufficient for performing factor analysis.

Table 5: EFA for Psychological Empowerment

\begin{tabular}{|l|r|r|r|c|}
\hline \multicolumn{5}{|c|}{ Pattern Matrix $^{\mathbf{a}}$} \\
\hline & 1 & 2 & 3 & 4 \\
\hline & .841 & & & \\
\hline EMP_MN1 & .925 & & & \\
\hline EMP_MN2 & .783 & & & \\
\hline EMP_MN3 & & & .849 & \\
\hline EMP_CM1 & & & .849 & \\
\hline EMP_CM2 & & & .521 & \\
\hline EMP_CM3 & & .557 & & \\
\hline EMP_SD1 & & .850 & & \\
\hline EMP_SD2 & & .872 & & \\
\hline EMP_SD3 & & & & \\
\hline
\end{tabular}




\begin{tabular}{|l|l|r|r|}
\hline EMP_IM2 & & .696 \\
\hline EMP_IM3 & & & .721 \\
\hline Total variance explained $-67.7 \%$ & \\
Determinant -0.032 & \\
KMO -0.692 & \\
\hline
\end{tabular}

Note: EMP_MN: Meaning; EMP_CM: Competence; EMP_SD: Self determination; EMP_IM: Impact

Source: Survey data

The Table 5 shows the factor structure of psychological empowerment constructs. The total variance explained by the subscales of empowerment is $67.7 \%$ and it is above the minimum requirement suggested by Hair et al (2006). The Determinant of the R-matrix which tests for multicollinearity is 0.032 and thus it can be assured that there are adequate interrelationships among the study items and none of the correlation coefficients are particularly large. Therefore, multicollinearity is not a problem for these data. The KMO value is 0.692 and it is above the acceptable limit and thus the sample is sufficient for performing factor analysis.

After confirming factor structure through EFA, the Confirmatory Factor Analysis (CFA) was performed using AMOS 20.0 to check validity and reliability of the study constructs. In CFA, Maximum Likelihood Estimation method was used and the validity and reliability of the subscales of study variables were assessed based on the results. Cronbach's alpha also was measured with the retained items for examining inter-item consistency. The results of CFA are shown in Table 6.

\section{Table 6: CFA Results of Study Constructs}

\begin{tabular}{|l|l|l|r|c|c|c|c|}
\hline & & Estimate & P & AVE & CR & $\begin{array}{c}\text { Cronbach's } \\
\text { alpha }\end{array}$ \\
\hline \multicolumn{2}{|l|}{ Transformational Leadership } \\
\hline ID_IN_A4 & $<-$--- & IIA & .704 & & & & \\
\hline ID_IN_A3 & $<---$ & IIA & .631 & $* * *$ & 0.513 & & \multirow{2}{*}{0.747} \\
\cline { 1 - 4 } ID_IN_A2 & $<---$ & IIA & .804 & $* * *$ & & 0.667 & 0.747 \\
\hline
\end{tabular}




\begin{tabular}{|c|c|c|c|c|c|c|c|}
\hline ID_IN_B4 & $<---$ & IIB & .686 & & \multirow{3}{*}{0.551} & \multirow[b]{3}{*}{0.765} & \multirow[b]{3}{*}{0.769} \\
\hline ID_IN_B2 & $<---$ & IIB & .667 & $* * *$ & & & \\
\hline ID_IN_B1 & $<---$ & IIB & .859 & $* * *$ & & & \\
\hline IN_CN4 & $<---$ & IND_CN & .815 & $* * *$ & \multirow[b]{2}{*}{0.809} & \multirow[b]{2}{*}{0.882} & \multirow[t]{2}{*}{0.846} \\
\hline IN_CN1 & $<---$ & IND_CN & .987 & & & & \\
\hline IN_MO2 & $<---$ & INS_MO & .618 & & \multirow[b]{2}{*}{0.516} & \multirow[b]{2}{*}{0.689} & \multirow[t]{2}{*}{0.680} \\
\hline IN_MO1 & $<---$ & INS_MO & .828 & $* * *$ & & & \\
\hline IN_ST3 & $<---$ & INT_STI & .622 & & \multirow[b]{3}{*}{0.4} & \multirow[b]{3}{*}{0.516} & \multirow[b]{3}{*}{0.721} \\
\hline IN_ST2 & $<---$ & INT_STI & .551 & $* * *$ & & & \\
\hline IN_ST1 & $<---$ & INT_STI & .639 & $* * *$ & & & \\
\hline \multicolumn{8}{|c|}{ Organizational Commitment } \\
\hline AF_CO6 & $<---$ & AF_COM & .704 & & \multirow{6}{*}{0.603} & \multirow{6}{*}{0.914} & \multirow{6}{*}{0.908} \\
\hline $\mathrm{AF} \_\mathrm{CO} 5$ & $<---$ & $\mathrm{AF} \_\mathrm{COM}$ & .681 & $* * *$ & & & \\
\hline $\mathrm{AF} \_\mathrm{CO} 4$ & $<---$ & AF_COM & .877 & $* * *$ & & & \\
\hline $\mathrm{AF} \_\mathrm{CO} 3$ & $<--$ & $\mathrm{AF} \_\mathrm{COM}$ & .893 & $* * *$ & & & \\
\hline $\mathrm{AF} \_\mathrm{CO} 2$ & $<---$ & $\mathrm{AF} \_\mathrm{COM}$ & .808 & $* * *$ & & & \\
\hline AF_CO1 & $<---$ & AF_COM & .661 & $* * *$ & & & \\
\hline CN_CO6 & $<---$ & CN_COM & .729 & & \multirow[b]{3}{*}{0.420} & \multirow[b]{3}{*}{0.577} & \multirow[b]{3}{*}{0.694} \\
\hline CN_CO5 & $<---$ & CN_COM & .602 & $* * *$ & & & \\
\hline CN_CO4 & $<---$ & CN_COM & .614 & $* * *$ & & & \\
\hline NO_CO6 & $<---$ & NO_COM & .679 & & & & \\
\hline NO_CO5 & $\mid<---$ & NO_COM & .761 & $* * *$ & & & \\
\hline NO_CO4 & $<---$ & NO_COM & .571 & $* * *$ & & & \\
\hline NO_CO3 & $<--$ & NO_COM & .822 & $* * *$ & & & \\
\hline NO_CO2 & $<---$ & NO_COM & .775 & $* * *$ & & & \\
\hline NO_CO1 & $<---$ & NO_COM & .595 & $* * *$ & 0.500 & 0.824 & 0.869 \\
\hline \multicolumn{8}{|c|}{ Psychological Empowerment } \\
\hline EMP_MN3 & $<--$ & EMP_MNG & .796 & & \multirow{3}{*}{0.679} & \multirow{3}{*}{0.983} & \multirow{3}{*}{0.856} \\
\hline EMP_MN2 & $<---$ & EMP_MNG & .909 & $* * *$ & & & \\
\hline EMP_MN1 & $<---$ & EMP_MNG & .759 & $* * *$ & & & \\
\hline EMP_CM2 & $<---$ & EMP_COM & .665 & $* * *$ & \multirow[b]{2}{*}{0.561} & \multirow[b]{2}{*}{0.842} & \multirow[t]{2}{*}{0.839} \\
\hline EMP_CM1 & $<---$ & EMP_COM & .812 & & & & \\
\hline
\end{tabular}




\begin{tabular}{|l|l|l|r|r|r|r|c|}
\hline EMP_SD3 & $<---$ & EMP_SDN & .864 & & & & 0.751 \\
EMP_SD2 & $<---$ & EMP_SDN & .711 & $* * *$ & 0.619 & 0.726 & \\
\hline EMP_IM3 & $<---$ & EMP_IMP & .616 & & & & \\
\hline EMP_IM1 & $<---$ & EMP_IMP & .734 & $* * *$ & & 0.633 & 0.813 \\
& & & & & 0.452 & & \\
\hline
\end{tabular}

Note: IIA: Idealized Influence-attributes; IIB: Idealized Influence-behaviour; INT_STI: Intellectual Stimulation; IND_CN: Individualized Consideration; INS_MO: Inspirational Motivation; EMP_MNG: Meaning; EMP_SDN: Self determination; EMP_COM: Competence; EMP_IMP: Impact; AF_COM: Affective Commitment; CN_COM: Continuance Commitment; NO_COM: Normative Commitment

Source : Survey data

\section{Validity and reliability}

The results of CFA reported in Table 6 show that the factor loadings for all the items measuring the sub-constructs of transformational leadership, except one item (IN_ST2), are above the minimum level of 0.6 (Awang, 2015) and the factor loading of IN_ST2 is above 0.5 which is also acceptable according to Hair et al. (2014). Therefore, unidimensionality is achieved for the transformational leadership constructs. Factor loadings for all of the items measuring the sub-constructs of organizational commitment, except one item (OC_NO6), and psychological empowerment are above 0.6. Thus, unidimensionality was achieved for the constructs organizational commitment and psychological empowerment.

Convergent validity: As per the results reported in Table 6, the requirement of convergent validity was fulfilled as the minimum standardized factor loadings for the items are above 0.6 (Joreskog \& Sorbom, 1979) except for few items and all loadings are significant at 0.001 level. In addition, as can be seen in the Table 6, the calculated value of Average Variance Extracted (AVE) is greater than the cut-off value of 0.5 (Hair, et al., 2014) for majority of the subscales of study constructs. The AVE for one of the subscale of transformational leadership namely intellectual stimulation (0.4), a subscale of organizational commitment namely continuance commitment (0.42) and a subscale of empowerment namely impact 
(0.452) are less than the cut-off point of 0.5 but the value above 0.4 is also acceptable according to Fornell and Larcker (1981). Therefore, the convergent validity is achieved for the subscales of transformational leadership, organizational commitment and psychological empowerment.

Construct validity: Construct validity is achieved for subscales all study constructs as the factor loadings exceed the minimum level 0.5 (Hair, et al., 2014) and the fitness indexes achieved the required level. The value of fitness indexes: CMIN/ $\mathrm{DF}=2.134$; CFI $=0.92$; TLI $=0.95$; and NFI $=0.98$ 0.9; and RMSEA $=0.056$. As the CMIN/DF is below the cut off value of 5 and most of the fitness indexes are above the cutoff point of 0.9 (Hair et al., 2014) and few indexes are very closer to 0.9 whereas the RMSEA is below the cut-off level of 0.08 (Hair et al., 2014).

Discriminant validity: Discriminant validity is achieved for the subscales of study constructs as the measurement models are free from redundant items. Among the subscales, the pairs of items with high value of Modification Indices (MI) were constrained as free parameter estimates. Further, the discriminant validity could be confirmed based on the AVE and the squared correlations between the constructs as depicted in Table 7. In the table, the diagonal values are the AVE of each sub-construct and the other values in the table are the squared correlations between the respective constructs. As can be seen in the table, as per the rule of thumb, the values of AVE are higher than the squared correlation values in the respective columns and the rows and thus discriminant validity is achieved (Hair et al., 2014) for the subscales of the study constructs.

Reliability: The Cronbach's alpha values reported in Table 6 show that the internal reliability of most of the sub-constructs is achieved as the alpha values exceed the cut-off level of 0.7 (Nunnally, 1978). At the same time, the alpha coefficient for one sub-construct of transformational leadership namely inspirational motivation is above 0.6 which is deemed to be acceptable as the alpha of other constructs are high (Godard et al., 2001; Hair et al., 2010; and Malhotra \& Peterson, 2006). The reliability is also achieved as the AVE for most of the subscales exceeded the minimum value of 0.5 (Hair et al., 2014) as reported in Table 6. In addition, as shown in Table 6, the calculated value of Composite Reliability (CR) was achieved 
as the values of $\mathrm{CR}$ exceeded the minimum required value of 0.6 (Hair et al., 2014) for the subscales of study constructs.

Table 7 : Mean and Discriminant validity

\begin{tabular}{|c|c|c|c|c|c|c|c|c|c|c|c|c|c|c|}
\hline & Mean & $\begin{array}{c}\text { Std. } \\
\text { Dev. }\end{array}$ & IIA & IIB & $\begin{array}{c}\mathrm{IND}_{-} \\
\mathrm{CN}\end{array}$ & $\begin{array}{c}\mathrm{INS}_{-} \\
\mathrm{MO}\end{array}$ & $\begin{array}{c}\mathrm{INT}_{-} \\
\mathrm{ST}\end{array}$ & $\begin{array}{l}\mathrm{AF}_{-} \\
\mathrm{COM}\end{array}$ & $\begin{array}{l}\mathrm{CO}_{-} \\
\mathrm{COM}\end{array}$ & $\begin{array}{l}\mathrm{NO}_{-} \\
\mathrm{COM}\end{array}$ & $\begin{array}{l}\text { EMP_- } \\
\text { MNG }\end{array}$ & $\begin{array}{c}\mathrm{EMP}_{-} \\
\mathrm{SDN}\end{array}$ & $\begin{array}{l}\mathrm{EMP}_{-} \\
\mathrm{COM}\end{array}$ & $\begin{array}{c}\mathrm{EMP}_{-} \\
\mathrm{IMP}\end{array}$ \\
\hline IIA & 3.11 & 0.55 & .513 & & & & & & & & & & & \\
\hline IIB & 4.12 & 0.73 & .206 & .551 & & & & & & & & & & \\
\hline IND_CN & 3.14 & 0.43 & .239 & .284 & .400 & & & & & & & & & \\
\hline INS_MO & 3.02 & 0.56 & .045 & .123 & .020 & 516 & & & & & & & & \\
\hline INT_STI & 3.01 & 0.41 & .235 & .357 & .264 & .064 & .809 & & & & & & & \\
\hline$\overline{\mathrm{AF} \_\mathrm{COM}}$ & 3.92 & 0.20 & .082 & .104 & .041 & .056 & .041 & .603 & & & & & & \\
\hline CO_COM & 3.16 & 0.64 & .001 & .001 & .007 & .004 & .007 & .008 & .420 & & & & & \\
\hline NO_COM & 3.20 & 0.47 & .005 & .027 & .031 & .006 & .031 & .016 & .133 & .500 & & & & \\
\hline EMP_MNG & 4.02 & 0.85 & .015 & .078 & .094 & .003 & .094 & .008 & .001 & .102 & .679 & & & \\
\hline EMP_SDN & 4.17 & 1.21 & .086 & .188 & .183 & .069 & .183 & .013 & .014 & .024 & .110 & .561 & & \\
\hline EMP_COM & 3.98 & 0.80 & .032 & .059 & .096 & .001 & .096 & .017 & .002 & .001 & .047 & .032 & 619 & \\
\hline EMP_IMP & 3.43 & 0.35 & .328 & .422 & .523 & .268 & .523 & .114 & .011 & .018 & .294 & .018 & .290 & .452 \\
\hline
\end{tabular}

To identify the relationships among the variables, the validated measurement models of the study constructs were integrated in the Structural Equation Model (SEM) as shown in Figure 1 and the results of SEM are reported in Table 8.

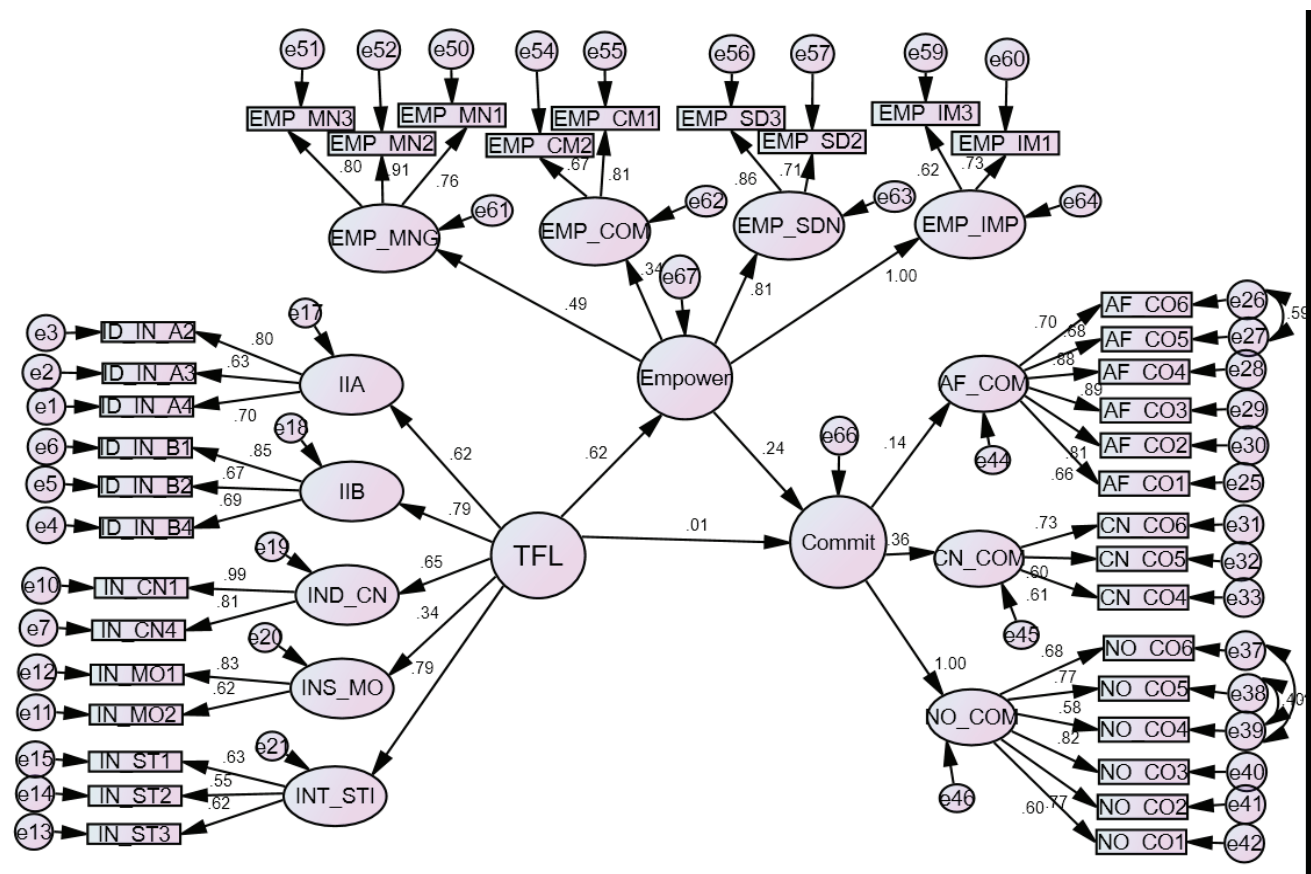


Note: TFL: Tranfromational Leadership; IIA: Idealized Influence-attributes; IIB: Idealized Influence-behaviour; INT_STI: Intellectual Stimulation; IND_CN: Individualized Consideration; INS_MO: Inspirational Motivation; EMP_MNG: Meaning; EMP_SDN: Self determination; EMP_COM: Competence; EMP_IM: Impact; AF_COM: Affective Commitment; CN_COM: Continuance Commitment; NO_COM: Normative Commitment

\section{Figure 1: Structural Equation Model}

\section{Table 8: Results of SEM}

\begin{tabular}{|l|r|r|}
\hline Parameter & Estimate & P \\
\hline TFL $\rightarrow$ Commitment & .011 & .924 \\
\hline TFL $\rightarrow$ Empowerment & .621 & .001 \\
\hline Empowerment $\rightarrow$ Commitment & .243 & .041 \\
\hline TFL $\rightarrow$ Empowerment $\rightarrow$ Commitment & .010 & .068 \\
\hline
\end{tabular}

Source: Survey Data

The results of SEM reported in Table 8 shows that the effect of transformational leadership style on organizational commitment is not significant ( $\beta$ std $=.011$, $\mathrm{p}=.924)$. Based on the results, H1: 'Transformational leadership style has a positive effect on organizational commitment' is not supported.

The results also reveal that transformational leadership has a significant positive effect on psychological empowerment $(\beta s t d=.621, p=.001)$. Therefore, H2: 'Transformational leadership style has a positive effect on psychological empowerment' is supported.

The mediating effect of psychological empowerment was examined using bootstrap method and 1000 bootstrap sample was generated and the bias corrected confidence was set as $95 \%$. The bootstrap results show that the direct effect of transformational leadership on organizational commitment is not significant ( $\beta$ std $=.011, \mathrm{p}=.924)$ and the indirect effect through the mediation of psychological empowerment also is not significant ( $\beta$ std $=.010, p=.068$ ). As both the direct effect and the indirect effect are not significant, it can be concluded that psychological empowerment doesn't mediate the effect of transformational leadership on organizational commitment. Therefore, the H3: 'Psychological empowerment mediates the effect of transformational leadership on organizational commitment' is not supported. 


\section{Discussion}

The current study revealed that transformational leadership doesn't have a positive effect on organizational commitment. The finding is not consistent with the previous studies conducted by Marmaya, Hitam, Torsiman and Balakrishnan (2011) and, Anwar and Ahmad (2012). A possible explanation for inconsistent results of the current study could be the context and nature of the public sector. The study of Marmaya et al (2011) was conducted in private sector in the Malaysian context. Thus, the leadership style which was effective in private sector in Malaysia context would not work best in the public sector in Sri Lanka. In addition, the participants of the current study were Development Officers who are operative level employees, the perceived leadership style reported by them were about their superiors who are first line leaders. Therefore, in the bottom level, some other styles such as transactional style or participative style would work best in promoting commitment and other behaviours.

The findings of the current study also found that transformational leadership has a positive effect on psychological empowerment. The results are in line with the studies reported in the literature (e.g. Pradhan, Panda, \& Jena, 2017; Suer, 2017). Transformational leaders empower followers by providing freedom to make decisions, positive emotional support and opportunities to experience task mastery. According to Bass (1985), followers can be empowered by encouragement and positive persuasion from the transformational leader. In line with these arguments, the positive effect of transformational leadership on empowerment of this study could be justified.

At the same time, psychological empowerment doesn't mediate the effect of transformational leadership on organizational commitment. The finding is not concurrent with the reported studies (e.g. Ismail et al., 2011; Ahmadi, 2014). The possible reason for the incongruent finding of the current study could be attributed to the sector and context. The finding of the current study differs from the study conducted by Ismail et al. (2011) as it was conducted in a US subsidiary firm operating in Malaysia. 


\section{Conclusion and Directions for Future Research}

The primary focus of this study was to examine the impact of transformational on organizational commitment and the mediating role of psychological empowerment in the relationship between the two constructs. The findings reported from this study bring great understanding of the relationship between the variables. From this study, it is evident that transformational leadership doesn't have significant impact on organizational commitment. In addition, the psychological empowerment doesn't have mediating effect in the relationship between transformational leadership on commitment. However, as per the results of SEM, the transformational leadership positively influences psychological empowerment. The study suggests that, to improve psychological empowerment, transformational leadership would be appropriate.

As the present study concludes transformational leadership is not effective in promoting commitment of Development Officers working at District and Divisional Secretariats, future research should cover other public sector and private sector organizations. As the operative level employees' perception of their superiors' (first line leaders) leadership style was studied, future studies need to focus on the middle and top level leaders' leadership styles and the resultant outcomes. In addition, the other leadership styles such as transactional and participative leadership could be considered as predictor of organizational commitment. The study could be further extended to the other public sector organizations as well as private sector organizations to confirm the results. 


\section{References:}

Abasilim, U. D., Obayan, A. I., Odukoya, A. J., Agbude, G., Wogu, I. A. P., \& Nchekwube, E. O. (2016). Transformational Leadership Style and Organizational Commitment Among Academic Staff in Covenant University Ota, Ogun State, Nigeria. Journal of Public Governance and Administration, 1(1), 40-49.

Abdulrab, M., Zumrah, A. R., Almaamari, Q., \& Al-Tahitah, A. (2017). Transformational Leadership and Psychological Empowerment in Malaysian Public Universities: A Review Paper. Development, 7(24).

Ahmadi, O. (2014). Impact of transformational leadership and psychological empowerment on organizational commitment in interior ministry. Management and Administrative Sciences Review, 3(3), 440-449.

Allameh, S. M., Heydari, M., \& Davoodi, S. M. R. (2012). Studying the relationship between transformational leadership and psychological empowerment of teachers in Abade Township. Procedia-Social and Behavioral Sciences, 31, 224-230.

Anwar, F., \& Ahmad, U. N. U. (2012). Mediating Role of Organizational Commitment among Leadership Styles and Employee Outcomes, An Empirical Evidence From Telecom Sector of Pakistan. International Journal of Research in Economics \& Social Sciences, 2(3), 116-151.

Ashforth, B. E. (1989). The experience of powerlessness in organizations. Organizational behavior and human decision processes, 43(2), 207-242.

Attari, M. (2013). The impact of transformational leadership on nurse psychological empowerment. International Journal of Hospital Research, 2(2), 71-76. http://ijhr.iums.ac.ir/article_4874_1776d2e9846e866af4425eac02c3c889.pdf

Avolio B.J., Zhu W., Koh W. \& Bhatia P. (2004). Transformational leadership and organizational commitment: mediating role of psychology empowerment and moderating role of structural distance. Journal of Organizational Behaviour, 25, 951-968.

Awang, Z., (2015). A Handbook on SEM. (2nd Ed.), Kaula Lumpur: Univerity of Sultan Zainal Abidin.

Bakan, I., Büyükbee, T., \& Erahan, B. (2011). An investigation of organizational commitment and education level among employees. International Journal of Emerging Sciences, 1(3), 231-245.

Balaji, M., \& Krishnan, V. R. (2014). Impact of transformational leadership on empowerment: Mediating role of social identity. International Journal on Leadership, 2(1), 34-42. 
Bass, B. M. (1985). Leadership and performance beyond expectations. New York: Free Press.

Bass, B. M., \& Avolio, B. J. (2000). MLQ Multifactor Leadership Questionnaire sample set: Technical report, leaders form, rater form, and scoring key for MLQ From 5x-Short. (2nd ed.). Redwood City, CA: Mind Garden.

Boamah, S. A., Laschinger, H. K. S., Wong, C., \& Clarke, S. (2018). Effect of transformational leadership on job satisfaction and patient safety outcomes. Nursing outlook, 66(2), 180-189.

Boonyarit, I., Chomphupart, S., \& Arin, N. (2010). Leadership, empowerment, and attitude outcomes. The Journal of Behavioral Science, 5(1), 1-14.

Buil, I., Martínez, E., \& Matute, J. (2019). Transformational leadership and employee performance: The role of identification, engagement and proactive personality. International Journal of Hospitality Management, 77, 64-75.

Burns, J.M. (1978). Leadership. New York: Harper Torchbooks

Conger, J. A., \& Kanungo, R. N. (1988). The empowerment process: Integrating theory and practice. Academy of Management review, 13(3), 471-482.

Deci, E. L., Connell, J. P., \& Ryan, R. M. (1989). Self-determination in a work organization. Journal of applied psychology, 74(4), 580.

Fang-guo, S. (2013, July). Multilevel model of transformational leadership and service quality: testing mediation role of psychological empowerment. In 2013 International Conference on Management Science and Engineering 20th Annual Conference Proceedings (pp. 1355-1362). IEEE.

Fornell, C. \& Larcker, D.F. (1981). Structural equation models with unobservable variables and measurement error: Algebra and Statistics. Journal of Marketing Research, 382-388

Gist, M. (1987). Self-efficacy: Implications for organizational behaviour and human resource management. Academy of Management Review, 12(3), 472-485.

Godard, C. D., Ehlinger, S., \& Grenier, C. (2001). Validity and reliability. In R. A. Thietart (Ed.), Doing Management Research: A Comprehensive Guide. London: SAGE Publications.

Hair Jr., J.F., Black, W.C., Babin, B.J., \& Anderson, R.E. (2010). Multivariate Data Analysis: A Global Perspective. (7th ed.). Upper Saddle River: Pearson Education

Hair, Jr. J. F., Black, W. C., Babin, B. J., Anderson, R. E., \& Tatham, R. L. (2006). Multivariate data analysis (6th ed.). Upper Saddle River, N.J: Pearson Prentice Hall. 
Hair, Jr. J.F., Black, W. C., Babin, B. J., \& Anderson, R. E. (2014). Multivariate data analysis: A global perspective. Pearson Education.

Han, S. H., Seo, G., Yoon, S. W., \& Yoon, D.-Y. (2016). Transformational leadership and knowledge sharing: Mediating roles of employee's empowerment, commitment, and citizenship behaviors. Journal of Workplace Learning, 28(3), 130-149.

Hater, J.J., \& Bass, B.M. (1988). Superiors' evaluations and subordinates' perceptions of transformational and transactional leadership. Journal of Applied Psychology, 73 (4) 695-702

Hutcheson, G. D., \& Sofroniou, N. (1999). The multivariate social scientist: Introductory statistics using generalized linear models. London: Sage Publications Ltd.

Ibrahim, N., Ismail, A., Mohamed, N., Salim, S., \& Yusuf, M. (2015). Effect of psychological empowerment and transformational leadership on organizational commitment. Makara Hubs-Asia, 19(2), 75-86.

Ismail, A., Mohamed, H. A. B., Sulaiman, A. Z., Mohamad, M. H., \& Yusuf, M. H. (2011). An empirical study of the relationship between transformational leadership, empowerment and organizational commitment. Business and Economics Research Journal, 2(1), 89-107.

Jha, S. (2013). Managerial Practices, Transformational Leadership, Customer Satisfaction and Self Efficacy as Antecedents of Psychological Empowerment: A Study of Indian IT Sector. Journal of Management Research, 13(2), 105.

Jin, Y. (2010). Emotional leadership as a key dimension of public relations leadership: National survey of public relations leaders. Journal of Public Relations Research, 22 (2), 159-181.

Joreskog, K.G., \& Sorbom, D. (1979). Advances in factor analysis and structural equation models. Cambridge, MA: Abt Books.

Kaiser, H. F., \& Rice, J. (1974). Little jiffy, mark IV. Educational and psychological measurement, 34(1), 111-117.

Kark, R., Shamir, B., \& Chen, G. (2003). The two faces of transformational leadership: empowerment and dependency. Journal of Applied Psychology, $88,264-255$.

Krishnan, V. R. (2012). Transformational leadership and personal outcomes: empowerment as mediator. Leadership \& Organization Development Journal, 33(6), 550-563. 
Lan, X. M., \& Chong, W. Y. (2015). The Mediating Role of Psychological Empowerment between Transformational Leadership and Employee Work Attitudes. Procedia-Social and Behavioral Sciences, 172, 184-191.

Lo, M., Ramayah, T., \& Min, H. (2009). Leadership styles and organizational commitment: A test on Malaysia manufacturing industry. African Journal of Marketing Management, 1, 133-139.

McCann, J. A., Langford, P. H., \& Rawlings, R. M. (2006). Testing Behling and McFillen's syncretical model of charismatic transformational leadership. Group \& Organization Management, 31(2), 237-263.

Malhotra, N., \& Peterson, M. (2006). Basic marketing research: A decision making approach. (2nd ed.). New Jersey: Prentice Hall.

Marmaya, N., Hitam, M., Torsiman N., \& Balakrishnan, B. (2011). Employees' perceptions of Malaysian managers' leadership styles and organizational commitment. African Journal of Business Management, 5(5), 1584-1588.

Martin, C. A., \& Bush, A. J. (2006). Psychological climate, empowerment, leadership style, and customer-oriented selling: an analysis of the sales manager-salesperson dyad. Journal of the Academy of Marketing Science, 34(3), 419-438.

Mathotaarachchi, K.P. (2013). The impact of transformational and transactional leadership behaviours on employees' trust and their organizational commitment for non-teaching staff of the Sri Lankan Universities. The Macrotheme Review: A multidisciplinary journal of global macro trends, 2(1), 56-92

Meyer, J. P., \& Allen, N. (1997). Commitment in the Workplace. Thousand Oaks: Sage Publications.

Mohammed, H. O., Aziz, A. I., Sadq, Z. M., \& Othman, B. A. (2020). The Impact of Transformation Leadership on Employee's Effectiveness (The Case of Ministry of Higher Education and Scientific Research, Kurdistan Regional Government, Iraq). International Journal of Multicultural and Multireligious Understanding, 7(11), 201-217.

Nunnally, J. C. (1978). Psychometric theory (2nd ed.). New York: McGraw-Hill.

Pradhan, R. K., Panda, M., \& Jena, L. K. (2017). Transformational leadership and psychological empowerment. Journal of Enterprise Information Management, 30(1), 82-95. https://doi.org/10.1108/JEIM-01-2016-0026

Raveendran, T., \& Gamage, A.S. (2019). The Mediating Effect of Organizational Commitment in the Impact of Transformational Leadership Style on Employee Performance: A Study of Divisional Secretariats in the Jaffna 
District. International Journal of Human Resource Studies, 9(2), 116-139. doi:10.5296/ijhrs.v9i2.14623

Robbins, S.P., \& Judge, T.A. (2007). Organizational Behavior (12th Ed.). Prentice Hall.

Rowold, J. (2005). Multifactor leadership questionnaire. Psychometric properties of the German translation by Jens Rowold. Redwood City: Mind Garden.

Sağnak, M., Kuruöz, M., Polat, B., \& Soylu, A. (2015). Transformational Leadership and Innovative Climate: An Examination of the Mediating Effect of Psychological Empowerment. Eurasian Journal of Educational Research, 60, 149-162.

Sarros, J. C., \& Santora, J. C. (2001). The transformational-transactional leadership model in practice. Leadership \& organization development journal, 22(8), 383-394.

Shah,T.A.,Nisar,M.,Rehman,K.,\&Rehman,I.(2011).Influenceoftransformational leadership on employees outcomes: mediating role of empowerment. African Journal of Business Management, 5(21), 8558- 8566.

Spreitzer, G. M. (1995). Psychological empowerment in the workplace: Dimensions, measurement, and validation. Academy of Management Journal, 38(5), 1442-1465. https://doi.org/10.5465/256865

Spreitzer, G. M. (2008). Taking stock: A review of more than twenty years of research on empowerment at work. Handbook of organizational behavior, 54-72.

Sreejesh, S., Mohapatra, S., \& Anusree, M. R. (2014). Business research methods: An applied orientation. Switzerland: Springer International Publishing

Suer, F. C. (2017). The Effect of leadership styles on employees' psychological empowerment and the gender role in this relation. Research Journal of Business and Management, 4(4), 434-446.

Thomas, K. W., \& Velthouse, B. A. (1990). Cognitive elements of empowerment: An "interpretive" model of intrinsic task motivation. Academy of management review, 15(4), 666-681.

Tsevaridou, L., \& Matsouka, O. (2019). The impact of leadership styles on employees' psychological empowerment, in greek sport departments. Sport Mont, 17(3), 73-78. 
Walumbwa, F. O., Avolio, B. J., \& Zhu, W. (2008). How transformational leadership weaves its influence on individual job performance: The role of identification and efficacy beliefs. Personnel Psychology, 61(4), 793-825. 